\title{
Penilaian Portofolio: Sikap terhadap Mata Pelajaran Kimia dan Hasil Belajar
}

\author{
Darma Putra \\ MAN 2 Kota Jambi
}

\begin{abstract}
Abstrak: Tujuan penelitian ini adalah untuk mengetahui korelasi penilaian portofolio dan sikap terhadap mata pelajaran kimia dengan hasil belajar. Hampir semua jenjang pendidikan formal menggunakan tes tertulis sebagai alat untuk mengevaluasi kemampuan peserta didik. Padahal dalam kenyataannya tes tertulis tidak selalu dapat diandalkan untuk mengukur kemampuan peserta didik. Portofolio yang mempertimbangkan dokumen tentang kerja peserta didik yang produktif yang menunjukan bukti tentang apa yang dapat dilakukan oleh peserta didik, bukan apa yang tidak dapat dikerjakan (dijawab atau dipecahkan) oleh peserta didik diprediksi memiliki kontribusi dalam meningkatkan hasil belajar. Penelitian ini adalah penelitian kuantitatif menggunakan metode korelasi diskriptif. Sebagai populasi adalah siswa-siswa Kelas X MAN Model Kota Jambi. Sampel penelitian kelas X Mia 3 yang diambil secara acak Dalam penelitian ini teknik pengumpulan data menggunakan teknik studi dokumentasi untuk memperoleh data tentang hasil penilaian portofolio $\left(\mathrm{X}_{1}\right)$ dan hasil belajar Kimia $(\mathrm{Y})$, dan angket untuk memperoleh data sikap terhadap mata pelajaran Kimia $\left(\mathrm{X}_{2}\right)$. Instrumen tes untuk memperoleh data hasil belajar. Instrumen telah divalidasi dan reliabel. Data penelitian yang diperoleh bersifat normal, homogen, dan linear. Kesimpulan dari penelitian ini adalah.(1) Terdapat hubungan positif yang signifikan antara hasil penilaian portofolio dan hasil belajar, (2) Terdapat hubungan positif yang signifikan antara sikap terhadap pelajaran Kimia dengan hasil belajar, (3) Terdapat hubungan positif dan signifikan antara penilaian portofolio dan sikap terhadap pelajaran Kimia secara bersama-sama terhadap hasil belajar. Konsekuensi logis dari hasil penelitian ini, dalam pembelajaran Kimia, diperlukan metode penilaian yang bervariasi yaitu seyogyanya menggunakan penilaian portofolio, pembelajaran kimia seharusnya dijadikan sebagai wahana dalam menumbuhkan sikap terhadap mata pelajaran kimia.
\end{abstract}

Kata-kata kunci: Portofolio; Sikap terhadap kimia; Hasil Belajar kimia

\section{Pendahuluan}

Ilmu Kimia merupakan salah satu bidang ilmu yang tergolong dalam ilmu Pengetahuan Alam (IPA) di samping Fisika, Geologi, Astronomi, dan Biologi. ${ }^{1}$ Ilmu Pengetahuan Alam adalah kelompok ilmu yang mempelajari gejala dan peristiwa alam, serta berusaha untuk mengungkapkan segala rahasia dan hukum alam. Obyek IPA meliputi asal-usul alam dengan segala isinya serta

1 Firman, Harry dan Liliasari, 2007. Kimia I . Jakarta: Departemen Pendidikan dan Kebudayaan. 
proses mekanisme dan karakter benda-benda maupun peristiwa alam. Artinya IPA bukan hanya sebagai kerangka informasi, tetapi juga untuk membantu memecahkan masalah-masalah praktis dalam kehidupan Seharihari serta membantu Siswa mengembangkan cara-cara berpikir logis. Kekhususan Ilmu Kimia yang membedakan dengan bidang ilmu IPA lainnya adalah bahwa Ilmu Kimia mengkhususkan pada pembahasan tentang struktur, susunan, sifat, dan perubahan materi, serta energi yang menyertai perubahan materi. Menurut Silberberg, ${ }^{2}$ peristiwa perubahan suatu materi (zat) menjadi zat lain disebut perubahan kimia.

Pendidikan kimia diharapkan dapat menjadi wahana bagi peserta didik untuk mempelajari diri sendiri dan alam sekitar, serta prospek pengembangan lebih lanjut dalam menerapkannya di dalam kehidupan sehari-hari. Proses pembelajarannya menekankan pada pemberian pengalaman langsung untuk mengembangkan kompetensi agar menjelajahi dan memahami alam sekitar secara ilmiah. Pendidikan kimia diarahkan untuk inkuiri dan berbuat sehingga dapat membantu peserta didik untuk memperoleh pemahaman yang lebih mendalam tentang alam sekitar.

Berdasarkan pengamatan sementara dalam pembelajaran kimia, masih ditemukan guru yang belum memiliki kemampuan dan keterampilan yang memadai dalam memilih serta menggunakan berbagai model pembelajaran dan model penilaian yang mampu mengembangkan iklim pembelajaran yang kondusif bagi siswa untuk belajar. Sehingga tidak sedikit siswa mengalami kesulitan dalam mengikuti proses belajar mengajar. Kondisi ini kurang mendukung pengembangan pengetahuan, sikap, moral, dan keterampilan siswa yang pada gilirannya, akan berpengaruh secara signifikan terhadap perolehan dan hasil belajar siswa.

Penilaian hasil belajar merupakan aktivitas yang sangat penting dalam proses pendidikan. Semua proses di lembaga pendidikan formal pada akhirnya akan bermuara pada hasil belajar yang diwujudkan secara kuantitatif berupa nilai. Pada umumnya guru menggunakan sistem penilaian tes tertulis yang memiliki kelemahan dalam hal mengukur kemampuan siswa secara paripurna. Guna menjawab berbagai kelemahan tes tertulis yang lazim digunakan tersebut, dikembangkan penilaian hasil belajar Portofolio yang mampu mendorong peserta didik untuk lebih aktif dan berusaha sekuat tenaga dalam mendayagunakan segala sumberdaya yang dimilikinya.

Haryati $^{3}$ menyebutkan bahwa portofolio merupakan proses penilaian yang berkelanjutan yang didasarkan pada kumpulan informasi yang menunjukan perkembangan kemampuan khususnya aspek psikomotor/unjuk kerja peserta didik dalam satu periode tertentu.

${ }^{2}$ Silberberg, Martin S, 2005. Chemistry: The Molecular Nature of Matter and Change Boston: McGraw Hill. H. 3.

${ }^{3}$ Haryati, Mimin. 2007. Model dan Teknik Penilaian pada Tingkat Satuan Pendidikan. Jakarta: Gaung Persada Press Jakarta, h. 58. 
Surapranata $^{4}$ mengungkapkan bahwa portofolio merupakan kumpulan dokumen berupa objek penilaian yang dipakai oleh seseorang, kelompok, lembaga, perusahaan atau sejenisnya yang bertujuan untuk mendokumentasikan dan mengavaluasi perkembangan suatu proses dalam mencapai tujuan yang telah ditetapkan. Suwandi ${ }^{5}$ menyatakan bahwa portofolio adalah kumpulan hasil karya, pekerjaan atau tugas-tugas peserta didik. Karya-karya disusun berdasarkan urutan kategori kegiatan sisiwa itu dipilih dan dinilai sehingga dapat menggambarkan perkembangan kemampuan atau kompetensi peserta didik.

Penilaian Portofolio bukan sekedar kumpulan hasil kerja peserta didik, melainkan kumpulan hasil peserta didik dari kerja yang sengaja diperbuat peserta didik untuk menunjukkan bukti tentang kompetensi, pemahaman, dan capaian peserta didik dalam mata pelajaran tertentu.

Selain aspek teknik penilaian dalam pembelajaran, aspek penting lain yang mempengaruhi hasil belajar adalah sikap siswa terhadap mata pelajaran. Sikap merupakan kecenderungan pola tingkah laku seseorang untuk berbuat sesuatu. Kecenderungan ini muncul setelah seseorang menghadapi suatu objek. Sikap ini akan tampak melalui pendapat, keyakinan, prefensi tingkah laku, pernyataan tentang fakta dan pernyataan mengenai tingkah laku mereka sendiri. Sebagaimana yang diungkapkan oleh Rokeach dalam Iskak ${ }^{6}$ bahwa sikap sebagai organisasi keyakinan yang relatif tetap tentang suatu atau situasi yang menimbulkan kecenderungan seseorang dengan cara tertentu.

Sikap merupakan suatu bentuk evaluasi atau bentuk reaksi perasaan seseorang terhadap objek tertentu. Sikap seseorang bisa bersifat mendukung jika yang dilakukan objek sesuai dengan yang diinginkan dan bersikap menolak apabila yang dilakukan oleh objek tidak sesuai dengan yang dinginkan. Sejalan dengan yang diungkapkan oleh Gagne ${ }^{7}$ bahwa sikap ialah keadaan internal yang membutuhkan tindakan pribadi yang ditunjukan kearah objek. Menurut Winkel ${ }^{8}$ orang yang bersikap tertentu cenderung menerima atau menolak suatu objek berdasarkan penilaian terhadap objek itu, berguna baginya atau tidak.

Dengan demikian sikap siswa terhadap mata pelajaran KIMIAadalah kesiapan siswa untuk memberikan respon positif atau negatif terhadap mata pelajaran IPA, yang ditunjukan melalui penilaian positif dan/atau negatif

\footnotetext{
${ }^{4}$ Surapranata, Sumarna \& Muhammad Hatta. 2004. Penilaian Portofolio, Implementasi Kurikulum 2004. Bandung: Rosdakarya., h. 26.

${ }^{5}$ Suwandi, Sarwiji. 2004. Model-Model Asesmen Dalam Pembelajaran. Surakarta: Yuma Pustaka, h. 110-111.

${ }^{6}$ Iskak, Mohammad. 2007. Pengaruh sikap belajar dan motivasi belajar terhadap prestasi belajar ilmu pengetahuan social. fenomena jurnal ilmiah ilmu social-humaniora, Vol.4. No. 2, juli 2007, h. 145-152.

7 Gagne, Robert M. 1989. The Condition of Learning and Theory of Instruction, Terjemahan Munadir. Jakarta: pau-ppai Universitas Terbuka, h. 54.

${ }^{8}$ Winkel, W. S. 2004. Psikologi Pengajaran. Yogyakarta: Media Abadi, h.211
} 
(kognisi), perasan untuk senang atau tidak senang (afeksi) dan kesediaan atau ketidaksediaan bertindak (konasi) terhadap mata pelajaran IPA.

Populasi dalam penelitian ini adalah siswa kelas X MAN Model Jambi yang berlokasi di Jln. adityawarman. Sedangkan sample penelitian ini adalah kelas X Mia 3 yang dipilih melalui random sampling. Pengumpulan data dilakukan dengan menggunakan teknik studi dokumentasi untuk data tentang hasil penilaian fortofolio $\left(\mathrm{X}_{1}\right)$ dan hasil belajar kimia (Y), dan instrumen angket untuk memperoleh data sikap terhadap mata pelajaran $\operatorname{kimia}\left(\mathrm{X}_{2}\right)$.

Instrumen penelitian yang digunakan telah melalui validasi sehingga layak digunakan untuk pengumpulan data. Data yang diperoleh telah memenuhi uji prasyarat hipotesis yakni uji normalitas, uji homogenitas dan uji linearitas. Analisis data untuk menguji hipotesis menggunakan korelasi product moment dan korelasi berganda.

\section{Hasil Penelitian}

Diskripsi data hasil penelitian ditujukan oleh tabel dibawah ini :

Tabel .1 Deskripsi Data Penelitian

\begin{tabular}{lccc}
\hline & \multicolumn{3}{c}{ Variabel } \\
\cline { 2 - 4 } Statistik Dasar & $\begin{array}{c}\text { Penilaian } \\
\text { Portofolio } \\
\left(\mathrm{X}_{1}\right)\end{array}$ & $\begin{array}{c}\text { Sikap terhadap } \\
\text { KIMIA(X })\end{array}$ & $\begin{array}{c}\text { Hasil Belajar } \\
\text { KIMIA } \\
(\mathrm{Y})\end{array}$ \\
\hline Mean & 72.59 & 115.24 & 27.45 \\
Median & 72.00 & 114.00 & 29.00 \\
Modus & 72.00 & 109.00 & 21.00 \\
Varian & 46.97 & 43.76 & 33.11 \\
Standar deviasi & 6.85 & 6.62 & 5.75 \\
Min & 63 & 105 & 18 \\
Max & 87 & 128 & 38 \\
\hline
\end{tabular}

Dengan bantuan program SPSS diperoleh korelasi antar variabel penelitian seperti yang ditunjukan pada tabel di bawah ini :

Tabel .2 Koefisien korelasi

\begin{tabular}{cccc}
\hline VARIABEL & $\mathbf{X}_{\mathbf{1}}$ & $\mathbf{X}_{\mathbf{2}}$ & $\mathbf{Y}$ \\
\hline $\mathbf{X}_{\mathbf{1}}$ & 1.000 & 0.819 & 0.779 \\
$\mathbf{X}_{\mathbf{2}}$ & 0.819 & 1.000 & 0.835 \\
$\mathbf{Y}$ & 0.779 & 0.835 & 1.000 \\
\hline
\end{tabular}


Pada pengujian hipotesis pertama diperoleh data hasil uji t pada $\alpha=5 \%$ dan $\mathrm{db}=\mathrm{n}-\mathrm{k}-1=27$ menunjukkan $t_{\text {hitung }}$ 6,5780 lebih besar dari nilai $\mathrm{t}_{\text {tabel }}=$ 2, 0518. maka $\mathrm{H}_{0}$ ditolak, yang berarti bahwa terdapat korelasi positif yang signifikan antara Hasil Penilaian Portofolio $\left(\mathrm{X}_{1}\right)$ dengan Hasil Belajar kimia (Y). Pada pengujian hipotesis kedua diperolehi data hasil uji t Untuk $\alpha=5 \%$ dan $\mathrm{db}=\mathrm{n}-\mathrm{k}-1=27$ menunjukkan thitung sebesar 8,0257, lebih besar dari $\mathrm{t}_{\text {tabel }}=2,0518$, maka $\mathrm{H}_{0}$ ditolak, yang berarti bahwa terdapat korelasi positif yang signifikan antara sikap terhadap kimia $\left(\mathrm{X}_{1}\right)$ dan Hasil Belajar kimia (Y).

Pada pengujian hipotesis ketiga melalui uji keberartian koefisien korelasi, dapat disimpulkan bahwa koefisien korelasi antara hasil penilaian portofolio dan sikap siswa terhadap mata pelajaran kimia dengan hasil belajar kimia adalah signifikan. Koefisien determinasi $\mathrm{R}^{2} \mathrm{x} 1 \mathrm{X} 2 \mathrm{Y}=0,938^{2}=$ 0,879, ini menunjukkan bahwa 87,9\% varian hasil belajar kimia ditentukan secara bersama-sama oleh hasil penilaian portofolio dan sikap siswa terhadap mata pelajaran kimia.

\section{Pembahasan}

Berdasarkan hasil analisis dengan menggunakan teknik korelasional, diperoleh hasil yang menunjukkan bahwa hasil penilaian portofolio memiliki korelasi positif dan signifikan dengan hasil belajar kimia. Keeratan korelasi antara kedua variabel tersebut ditunjukkan oleh koefisien korelasi $\mathrm{r}_{\mathrm{x} 1 \mathrm{y}}=$ 0,779 signifikan pada 0,05. Karena korelasinya positif, maka hal ini mengandung makna bahwa semakin baik hasil penilaian portofolio akan semakin baik pula hasil belajar siswa.

Teknik penilaian portofolio menuntut siswa untuk lebih aktif dalam menyiapkan materi dengan baik, adanya umpan balik (review guru) pada setiap tahapannya mendorong siswa untuk dapat menghasilkan sebuah karya yang optimal. Hal ini sejalan dengan yang di ungkapkan oleh Darmansyah bahwa ketika siswa mendapat rangsangan yang menyenangkan dari lingkungan akan terjadi berbagai sentuhan tingkat tinggi pada diri siswa yang akan membuat mereka lebih aktif, kreatif secara mental dan fisik.

Portofolio akan mengakibatkan proses pembelajaran menjadi efektif karena adanya proses "menemukan" pengetahuan dan dimensi lainnya yang penting. Belajar dengan cara penemuan akan menekankan penilaian ini menuntut beberapa kemampuan siswa, seperti kemampuan mengungkapkan tulisan, menganalisis tulisan dan menjawab masalah yang dapat meningkatkan daya pikir dan kreativitas terhadap materi pembelajaran. Hal ini sejalan dengan yang di kemukakan oleh Melvin L. Silberman, menurutnya bahwa agar belajar menjadi aktif maka siswa harus menggunakan otak dengan cara mengkaji suatu gagasan, memecahkan masalah dan menerapkan apa yang mereka pelajari selain itu belajar aktif harus penuh semangat, bergerak leluasa dan berfikir keras (moving about and thinking aloud). Hal ini mengungkapkan bahwa pembelajaran by doing dapat memaksimalkan hasil yang di peroleh karena hasil belajar siswa tidak hanya di simpan dalam short 
term memory tapi dapat dilanjutkan ke long term memory. Melalui teknik penilaian portofolio, siswa dapat melakukan perbaikan terhadap hasil karya mereka masing-masing dan dapat mengidentifikasi kekurangankekurangannya dalam karya tulisnya untuk perbaikan pada aktivitas belajar berikutnya. Pentingnya bagi si pelajar (student centered) portofolio akan mendorong siswa untuk aktif dan kreatif. Sehingga siswa bisa menghubungkan berbagai ide, fakta dan teknik menjadi sebuah pola yang lebih mudah di pahami.

Temuan penelitian di atas sejalan dengan temuan penelitian Nufus ${ }^{9}$ yang menyebutkan bahwa pendekatan peserta didik yang diberi penilaian portofolio lebih tinggi nilai hasil belajarnya dari peserta didik yang diberi penilaian tes tertulis. Juga sejalan dengan hasil penelitian Munawar ${ }^{10}$ yang melakukan penelitian pada MTs Ma`rif Jatinangor, hasil penelitiannya menunjukan bahwa terdapat perbedaan yang signifikan antara peserta didik yang dinilai menggunakan teknik portofolio dengan hasil belajar peserta didik yang menggunakan tes uraian. Pada mata pelajaran matematika juga memiliki kesamaan sebagaimana ditunjukkan oleh hasil penelitian Sunandar ${ }^{11}$ yang melakukan penelitian pada SMA Negeri 4 Kendari, hasil penelitiannya menunjukan bahwa hasil belajar matematika peserta didik yang diberi penilaian portofolio lebih tinggi dari peserta didik yang diberi penilaian konvensional.

Hasil pengujian hipotesis kedua menunjukkan behwa terdapat korelasi yang positif dan signifikan antara sikap siswa terhadap mata pelajaran kimia dengan hasil belajar kimia. Korelasi ini ditunjukkan oleh koefisien $r_{x 2 y}=0,835$ yang signifikan pada 0,05 . Karena korelasi tersebut positif maka dapat dimaknai bahwa semakin positif sikap siswa terhadap mata pelajaran kimia maka semakin baik pula hasil belajar siswa.

Siswa yang memiliki sikap positif terhadap pelajaran kimia, akan menganggap pelajaran kimia sebagai mata pelajaran yang menyenangkan, sehingga siswa memiliki inisiatif dalam mengelola kegiatan belajarannya secara personal, mengevaluasi kelemahan dan kekuatan dihubungan dengan tugas belajar, termasuk di dalamnya dalam melakukan aktivitas belajar yang baik. Hal ini sejalan dengan yang ditemukan oleh Papanastasiou dan Zembylas dalam Anwer ${ }^{12}$ bahwa terdapat korelasi positif antara sikap siswa terhadap pelajaran sains dengan penilaian yang diperolehnya, sikap

${ }^{9}$ Nufus, Neni Hayati. 2009. Pengaruh Pendekatan Penilaian Portofolio Dan Tes Tertulis Terhadap Hasil Belajar Ilmu Pengetahuan Alam Dengan Mengontrol Perbedaan Pengajar. Disertasi. Jakarta: Program Pascasarjana Universitas Negeri Jakarta, h. 209.

10 Munawar, Mumun.2010. Pengaruh Bentuk Penilaian Dan Metode Pembelajaran Terhadap Hasil Belajar Matematika. Tesis: Program Pascasarjana Universitas Negeri Jakarta.

${ }_{11}$ Sunandar. 2010. Pengaruh Penilaian Porotofolio Dan Kecerdasan Emosional Terhadap Hasil Belajar Matematika Topic Dimensi Tiga Peserta Didik Kelas X Sma Negeri 4 Kendaritahun 2004. Kendari, Semnas Matematika Dan Pendidikan Matematika.

12 Anwer, Muhammad Dan Hafiz Muhammad Iqbal. 2012. Student's Attitude Toward Science: A Case Of Pakistan." Pakistan Journal Of Social And Psychology. Vol 9. No 2, April 2012, h. 3-9. 
seseorang terhadap mata pelajaran dapat mempengaruhi levelnya. Begitu pula yang ditemukan oleh Russsel dan Hollander dalam Movahedzadeh ${ }^{13}$ bahwa: The tool was developed on the assumptionthat an important consequence of instruction is a positive change in the student's attitude toward the subject, and theauthors argue the importance of focusing on attitudes by statingthat there usually exists a positive correlation between attitudes and achievement.

Sikap menunjukan kecenderungan seseorang dalam melakukan suatu hal. Siswa yang memiliki sikap positif terhadap kimia juga akan bereaksi positif dalam menghadapi pelajaran tersebut. Ini berarti bahwa dalam proses pembelajaran siswa akan memberikan usaha yang maksimal, senang dan cenderung aktif dalam proses belajar.

Hasil pengujian hipotesis ketiga membuktikan bahwa terdapat korelasi positif dan signifikan antara hasil penilaian portofolio dan sikap siswa terhadap mata pelajaran kimia secara bersama-sama terhadap hasil belajar kimia. Koefisien determinasi adalah $\mathrm{R}^{2} \mathrm{x} 1 \mathrm{X} 2 \mathrm{Y}=0,938^{2}=0,879$, ini menunjukkan bahwa 87,9\% varian hasil belajar kimia ditentukan secara bersama-sama oleh hasil penilaian portofolio dan sikap siswa terhadap mata pelajaran kimia.

Diperolehnya koefisien determinasi sebesar 0,879 pada hasil pengujian hipotesis ini menunjukkan bahwa faktor penilaian portofolio dan sikap siswa terhadap mata pelajaran kimia memberikan kontribusi terhadap hasil belajar kimia, namun demikian masih terdapat sebesar 12,1\% faktor lain selain faktor penilaian portofolio dan sikap siswa terhadap mata pelajaran kimia yang tidak terungkap dalam penelitian ini dapat mempengaruhi hasil belajar kimia.

\section{Penutup}

Berdasarkan temuan dan mempertimbangkan keterbatasan penelitian ini, disimpulkan sebagai berikut (1) Terdapat korelasi positif dan signifikan hasil penilaian portofolio dengan hasil belajar kimia. Hal ini berarti semakin tinggi hasil penilaian portofolio yang dicapai siswa maka semakin tinggi pula hasil belajar siswa, (2) Terdapat korelasi yang positif dan signifikan sikap siswa terhadap mata pelajaran kimia dengan hasil belajar kimia. Ini bermakna bahwa semakin positif sikap siswa terhadap mata pelajaran kimia maka semakin tinggi pula hasil belajar kimia siswa yang bersangkutan, (3) terdapat korelasi yang positif dan signifikan hasil penilaian fortofolio dan sikap siswa terhadap mata pelajaran kimia secara bersama-sama dengan hasil belajar siswa dalam mata pelajaran kimia. Hal ini berarti semakin tinggi hasil penilaian portofolio dan semakin positif sikap siswa terhadap mata pelajaran kimia, maka semakin tinggi pula hasil belajar kimia siswa yang bersangkutan.

\footnotetext{
${ }^{13}$ Movahedzadeh, Farahnat. 2011. Improring Students' Affitude Foward Science Trought Blended Learning. Artikel. Science Education and Civic Engogement.(3) (2) Sumer 2011, h. 14.
} 
Konsekuensi logis dari hasil penelitian ini adalah diperlukan metode penilaian yang bervariasi yaitu seyogyanya menggunakan penilaian portofolio dalam pembelajaran kimia dan pembelajaran kimia seharusnya dijadikan sebagai wahana dalam menumbuhkan sikap terhadap mata pelajaran kimia.

\section{BIBLIOGRAFI}

Anwer, Muhammad Dan Hafiz Muhammad Iqbal. 2012. Student's Attitude Toward Science: A Case Of Pakistan." Pakistan Journal of Social And Psychology.Vol 9. No 2, April 2012.

Firman, Harry dan Liliasari, 2007. Kimia I . Jakarta: Departemen Pendidikan dan Kebudayaan.

Gagne, Robert M. 1989. The Condition of Learning and Theory of Instruction, Terjemahan Munadir. Jakarta: pau-ppai Universitas Terbuka.

Haryati, Mimin. 2007. Model dan Teknik Penilaian pada Tingkat Satuan Pendidikan. Jakarta: Gaung Persada Press Jakarta.

Iskak, Mohammad. 2007. Pengaruh sikap belajar dan motivasi belajar terhadap prestasi belajar ilmu pengetahuan social. fenomena jurnal ilmiah ilmu social-humaniora, Vol.4. No. 2, juli 2007.

Movahedzadeh, Farahnat. 2011. Improring Students' Affitude Foward Science Trought Blended Learning. Artikel. Science Education and Civic Engogement.(3) (2) Sumer 2011.

Munawar, Mumun.2010. Pengaruh Bentuk Penilaian Dan Metode Pembelajaran Terhadap Hasil Belajar Matematika. Tesis: Program Pascasarjana Universitas Negeri Jakarta.

Nufus, Neni Hayati. 2009. Pengaruh Pendekatan Penilaian Portofolio Dan Tes Tertulis Terhadap Hasil Belajar Ilmu Pengetahuan Alam Dengan Mengontrol Perbedaan Pengajar. Disertasi. Jakarta: Program Pascasarjana Universitas Negeri Jakarta.

Silberberg, Martin S, 2005. Chemistry: The Molecular Nature of Matter and Change Boston: McGraw Hill.

Sunandar. 2010. Pengaruh Penilaian Porotofolio Dan Kecerdasan Emosional Terhadap Hasil Belajar Matematika Topic Dimensi Tiga Peserta Didik Kelas X Sma Negeri 4 Kendaritahun 2004. Kendari, Semnas Matematika Dan Pendidikan Matematika.

Surapranata, Sumarna \& Muhammad Hatta. 2004. Penilaian Portofolio, Implementasi Kurikulum 2004. Bandung: Rosdakarya.

Suwandi, Sarwiji. 2004. Model-Model Asesmen Dalam Pembelajaran. Surakarta: Yuma Pustaka.

Winkel, W. S. 2004. Psikologi Pengajaran. Yogyakarta: Media Abadi. 